\title{
Forensic investigation of burnt human remains
}

This article was published in the following Dove Press journal:

Research and Reports in Forensic Medical Science

10 December 2015

Number of times this article has been viewed

\section{Kazuhiko Imaizumi}

National Research Institute of Police Science, Kashiwa, Japan
Correspondence: Kazuhiko Imaizumi National Research Institute of Police Science, 6-3-I Kashiwanoha, Kashiwa, Chiba 277-0882, Japan

Tel $+8|47| 35800$ l ext 2320

Fax +81471339159

Email imaizumi@nrips.go.jp

\begin{abstract}
In forensic casework, it is vital to be able to obtain valuable information from burnt bone fragments to ascertain the identity of the victim. Burnt bones show significant alterations both in physical and in chemical properties, and these could be obstacles to anthropological tests and DNA profiling. Heat increases the difficulties of bone identification, depending on the exposure temperature. We therefore need to collate detailed information on bone alterations during burning and the influence on appropriate interpretation of observations and test results. This review summarizes the alterations that occur in bone during the burning process, particularly focusing on coloration, weight reduction, shrinkage, deformation, fragmentation, and DNA survival. In addition, the application of micro-computed tomography imaging to burnt bone identification is introduced as one of the most advanced technologies for anthropological analysis.
\end{abstract}

Keywords: burnt remains, burnt bone, cremation, DNA degradation, micro-CT

\section{Introduction}

In forensic casework, we frequently encounter cases where burnt bones are submitted for identification. Properties of bone, both physical and chemical, change drastically during burning and these changes cause difficulties in forensic identification tests. Physical changes occurring in burnt bone, such as deformation and fragmentation due to heat-induced shrinkage, alter the morphological indicators that are critical for anthropometric analysis of species, sex, age, and stature estimation. In addition to the physical alterations, heat in the burning process also induces chemical modification of bones due to combustion and pyrolysis of chemical substances. The degree of modification increases with rising temperatures, and includes degradation of DNA, which compromises forensic identification techniques. We therefore need to know details of these problematic influences, as well as consider the degree of heat to which the specimen had been exposed. Such information will help forensic scientists to interpret test results obtained from burnt bones more accurately.

Many studies regarding burnt bone identification have been published, and their results are summarized in book chapters and reviews. ${ }^{1-12}$ Besides those issues associated with laboratory analysis of burnt bones, topics covered relate to pre-laboratory operations such as evidence recovery from the scene, ${ }^{13-16}$ the importance of artificial materials associated with burnt bones, ${ }^{17,18}$ collection strategy for burnt bones in commingled circumstances, ${ }^{16,17}$ as well as the fundamentals of burning and cremation. ${ }^{1,4,5,18}$

This review focuses on the challenging alterations to burnt bones that make laboratory testing difficult, particularly in conventional anthropological and DNA analysis. 
These alterations will be summarized and a newly applied method for burnt bone identification, micro-computed tomography (micro-CT) imaging, will also be introduced.

\section{Burnt bones in forensic cases}

There is a wide range of case types for which burnt bones are submitted to the forensic laboratory, ${ }^{14-16,19-25}$ including fire victims in vehicle accidents, ${ }^{14,15}$ from mass disasters, ${ }^{14}$ and in house fires. ${ }^{16,22}$ In addition to accidental cases, we encounter homicides where the victim's body is purposely cremated and destroyed by the perpetrator in order to obstruct the investigation. ${ }^{15,16,20-24,26}$ Heat-induced fragmentation of burnt bones followed by artificial crushing makes meaningful anthropological observation difficult. Additionally, DNA analysis of severely burnt bones can be extremely difficult.

\section{Coloration of burnt bones}

Bone changes color drastically when it is burnt. Since the color of the bone surface varies with exposure temperature, many researchers have attempted to find a correlation between bone color and burning temperature in order to establish an index for estimating the exposure temperature of questioned bone samples. ${ }^{1-3,5,6,9,11,12,27-32}$ The degree of bone coloration also varies with burning time, and a long period of burning results in more severe color alteration. ${ }^{3,28}$ Anaerobic burning conditions delay the coloration process. ${ }^{3}$ The soft tissues of a corpse act as a physical barrier against the flames at the start of combustion and keep bones in anaerobic conditions. The unevenness of soft tissue thickness in the body and an unequal distribution of heat during the burning itself often result in varying degrees of burnt bones even in the same individual. ${ }^{4,20,23,33-35}$ Results from experimental studies on bone coloration using naked (defleshed) compact bone samples all give slightly different results, ${ }^{1-3,5,6,28,30,32}$ possibly because there are differences in sample size, type of furnace, oxygen supply, burning time, as well as the color names used in each study. ${ }^{10}$ Though these differences should not be overlooked, we may regard the correlation between bone color and temperature as follows: a yellow-brown at $200^{\circ} \mathrm{C}$, a dark brown-black at $300^{\circ} \mathrm{C}-400^{\circ} \mathrm{C}$, an ash-like gray at $500^{\circ} \mathrm{C}-600^{\circ} \mathrm{C}$, and a chalk-like white at excess of $700^{\circ} \mathrm{C}$. These alterations were shown in photographs and colored charts in previous reports. ${ }^{3,28}$ There are attempts to measure colors of burnt bones digitally using a colorimetry method based on the CIELAB (LAB based color model adopted by Comission Internationale de l'Eclairage, CIE) color space., ${ }^{2,36}$ Fredericks et al studied the correlation between burnt bone coloration and success of DNA typing. ${ }^{36}$ They applied the
CIELAB colorimetry and conventional Munsell color scoring method for bone color description and concluded that there is potential for the color to be a diagnostic tool for the viability of DNA testing. ${ }^{37}$ The colorimetry technique provides a highly objective and reproducible analysis, so it is expected to be applied in the future of burnt bone identifications.

\section{Weight reduction of burnt bones}

During burning, bone weight is reduced because of water vaporization and combustion of organic materials which releases the carbon mainly in the form of carbon dioxide. ${ }^{1,6,9,38}$ Complete cremation of a human body leaves approximately 2,000 and 3,000 $\mathrm{g}$ of cremated female and male bones, respectively. ${ }^{39,40}$ Several studies have monitored the weight reduction of experimentally burnt bones and showed immediate weight reduction after heating. ${ }^{28,36,38,41-43}$ Though this decrease is drastic up to $400^{\circ} \mathrm{C}$, it tends toward a plateau at approximately $700^{\circ} \mathrm{C}$, stabilizing at approximately $60 \%$ of the original weight. According to Ortner and Turner-Walker, ${ }^{44}$ compact bone is composed of $14 \%$ water and $24 \%$ organic matrix (by weight), with the remaining $62 \%$ classified as bone mineral, which would not be released through burning. Therefore, it could be said that burnt bone loses water and a significant amount of the organic matrix by $400^{\circ} \mathrm{C}$ and loses the organic matrix completely approximately $700^{\circ} \mathrm{C}$. Fredericks et al performed Fourier transform infrared spectroscopy (FTIR) on burnt bone powder to monitor the decrease of collagen by measuring the amide-to-phosphate ratio. ${ }^{45}$ They showed a drastic decrease of collagen at temperatures between $200^{\circ} \mathrm{C}$ and $400^{\circ} \mathrm{C}$, becoming milder toward $700^{\circ} \mathrm{C}$, at which the collagen became no longer detectable. This supports the aforementioned description of the decrease of the organic matrix in burnt bones. We should consider this early decrease of the organic matrix when applying DNA tests to burnt bones since DNA is an organic component of the bone.

\section{Shrinkage and deformation of burnt bones}

Bone also reduces in volume through the burning process. Though this is one of the major alterations occurring in burnt bones, a quantitative analysis of volume reduction has not been established because of the difficulty of precise volume measurement in its cracked and fragmented form. Recent $\mathrm{X}$-ray computed tomography (CT) technology enabled the digital volume measurement of complex shapes and has been applied to volume analysis of burnt bones. ${ }^{28,46}$ Analysis with micro-CT produced accurate volume reduction measurements of cubically cut, burnt compact bone. ${ }^{28}$ In contrast 
to the weight alterations described earlier, the volume do not change until $600^{\circ} \mathrm{C}$, but then decreased considerably above this temperature up to at least $1,100^{\circ} \mathrm{C}$, by which temperature the bone volume is almost halved. This shrinkage occurs through a combination of losing collagen, ${ }^{36,45}$ recrystallization of the hydroxyapatite (thus increased crystallinity), ${ }^{6,45}$ chemical alteration of the hydroxyapatite to beta-tricalcium phosphate, ${ }^{6,9,38,42}$ and the fusion of these crystals. ${ }^{6,9}$

This shrinkage and subsequent significant deformation causes problems for anthropometric tests. The influence it has on morphology ranges from the gross to the microscopic level. Gonçalves performed anthropometric analysis on cremated femur (only the proximal extremity), talus, and calcaneus obtained from 84 adult remains cremated in a modern crematorium. ${ }^{47}$ The statistically significant results showed that sexual dimorphisms were conserved even in shrunk specimens. However, those anthropometric standards established for sex estimation of non-burnt (normal) bones did not produce an effective estimation in male specimens because shrinkage caused a reduction of measurements. An anthropometric study on experimentally burnt sheep bones revealed significant changes of the measurements, not only a reduction but also an expansion, resulting from complicated shape alteration during the shrinkage process. ${ }^{27}$ Even in bones which have been shrunk, identification based on morphological characteristics is still possible. Some investigators have applied the use of frontal sinus morphology, and dentition to burnt bone identification and successfully established identities of the victims. ${ }^{25,26,48,49}$ Histomorphological studies on experimentally burnt bones have also been reported. ${ }^{50-52}$ Both Nelson, and Bradtmiller and Buikstra assessed the application of the histomorphological age estimation method to samples of burnt compact bone. ${ }^{50,51,53-59}$ These studies examined osteons and Haversian canals under microscopy. It was found that the histological structures needed for age estimation were identifiable in bones burnt at between $1,000^{\circ} \mathrm{F}\left(538^{\circ} \mathrm{C}\right)$ and $1,500^{\circ} \mathrm{F}\left(816^{\circ} \mathrm{C}\right)$, and at $600^{\circ} \mathrm{C}$. The former study by Nelson revealed significant shrinkage of microstructural elements after burning, while the latter tentatively concluded that the shrinkage does not appear to have a significant effect on age estimation. The other use for histological observation of burnt fragmented bones is species identification. Mean sizes of the osteon and the Haversian canal significantly differ among species, ${ }^{52,60-63}$ and animal bones tend to have a lamellar pattern formed by primary osteons that is absent in adult human bones. ${ }^{53,64,65}$ Cattaneo et al experimentally burnt compact bones of humans and of several animals (cow, horse, pig, and sheep) and successfully discriminated human or non-human origin from the microscopic observation. ${ }^{52}$

Because the shrinkage continues even after weight reduction has ceased, the density of the compact bone increases at higher temperature $\left(>500^{\circ} \mathrm{C}\right)$ and this results in bone hardening. The hardness of the burnt bone has been measured by Fredericks et al using the Vickers hardness method. ${ }^{10,36}$ Their results showed that after an initial slight hardening occurred below $150^{\circ} \mathrm{C}$, the compact bone became brittle when the combustion weakened the collagen structures, and then hardening started at $400^{\circ} \mathrm{C}$. The hardening accelerated above $700^{\circ} \mathrm{C}$, coinciding with increasing crystallinity measured as a splitting factor by the FTIR..$^{31,45,66}$ In the process of recrystallization, a variety of sizes and shapes of the crystals can be observed using a scanning electron microscope at high magnification. ${ }^{30,34}$ Dramatic shape changes observed as spherical, hexagonal, platelets, and rosettes occur in the growth of the crystals at above $600^{\circ} \mathrm{C}$. The formation of these unique shapes depends not only on the temperature exposure but also on the age of the individual. ${ }^{45}$ Several studies examined this recrystallization from the crystal chemistry perspective. ${ }^{31,32,38,42,43}$ They clearly revealed temperaturedependent structural alteration of the crystal by using X-ray diffraction, small-angle X-ray scattering, and FTIR. It is possible to apply these protocols in estimating the exposure temperature of the bone specimens.

The shrinkage mechanism produces cracks in the burnt bone. Under optical microscope observation, the minute cracks that tend to arise from the Haversian canal can be seen above $500^{\circ} \mathrm{C}$, and cracks increase in number and size at higher temperatures. ${ }^{28}$ Other studies also found such initial cracks at lower temperature $\left(100^{\circ} \mathrm{C}-300^{\circ} \mathrm{C}\right)$ and at higher temperature (above $1,000^{\circ} \mathrm{C}$ ). ${ }^{30,67}$ After $1,150^{\circ} \mathrm{C}$ exposure, this cracking was also observed using the scanning electron microscope as a form of multiple fissures. ${ }^{29}$

\section{Fragmentation of burnt bones and survival of trauma made on bones}

The formation of cracks in the hardened material triggers a fragmentation. Burnt bones exhibit fragmented forms in different degrees and this creates difficulties in the identification attempts. One of the techniques often applied to bone fragments in the identification process is reconstruction. Grèvin et al reported a case where a human mandible was successfully reconstructed from the burnt bone fragments. ${ }^{48}$ They stressed the need for high-level expertise in burnt bone identification because of the severity of fragmentation. Waterhouse examined the course of post-burning fragmentation 
using pig limbs and found that a short-term recovery delay of 24 hours increased the degree of fragmentation. ${ }^{68}$ Another study by the same author revealed that some weather conditions, such as freezing or fluctuating temperatures, or wet conditions also enhanced bone fragmentation. ${ }^{69}$ The results of these two studies highlight the importance of prompt collection of burnt bones from the scene.

In murder cases, it is important to identify the evidence of trauma on the burnt bone, and attempt to describe the weapon used. ${ }^{19,22}$ Pope and Smith experimentally cremated injured heads of dead bodies and confirmed the persistence of the signs of ballistic, blunt force, and sharp force traumas even after burning. ${ }^{70}$ They also examined the heat-related fractures produced in the burning and pointed out the differences in pre-existing traumatic fractures in terms of edge sharpness. Poppa et al examined survival of simulated trauma to pig heads after burning. ${ }^{71}$ The sharp force trauma (made using a saw, hatchet, and screw driver), blunt force trauma made with a hammer, and ballistic trauma were all identifiable even in completely cremated skulls. A detailed examination of saw marks was completed by Robbins et al. ${ }^{72}$ They prepared 12 kinds of saw blade and made cuts of varying depth to pig long bones. These saw marks survived well even in calcined bones. In relation to gunshot trauma, the soot staining that appears around a gunshot wound has also been studied. Amadasi et al experimentally burnt bovine ribs after they were shot with a firearm and found that the soot stains could be identified even after being burnt at $800^{\circ} \mathrm{C}$ despite their color having changed to be more yellowish. ${ }^{73}$

\section{DNA survival in burnt bones}

Recent progress of DNA analysis techniques is improving its discrimination power and sensitivity on an ongoing basis and now this technique is routinely applied to the identification of skeletal remains. ${ }^{74-76}$ DNA profiling was expected to be a useful tool for identifying severely burnt bones when morphological tests would fail because of the deformation and fragmentation. However, casework we have encountered and studies published on burnt bone DNA typing show the harsh reality of this application. As mentioned earlier, the organic matrix disappears at a comparatively early phase in the burning process, and DNA is no exception.

Several studies have reported the applicability of DNA typing to the investigation of burnt bones. ${ }^{28,33,36,45,52}$ As a pioneer of experimental study in this area, Cattaneo et al assessed the amplification of $120 \mathrm{bp}$ products of the human mitochondrial DNA region $\mathrm{V}$ in experimentally burnt human compact bones $\left(800^{\circ} \mathrm{C}-1,200^{\circ} \mathrm{C}\right.$, for 20 minutes) as well as in charred bones obtained from actual forensic cases. ${ }^{52}$ They found that none of these burnt specimens retained DNA that was amplifiable and concluded that DNA typing cannot be used successfully with charred bones. They selected the temperature of $800^{\circ} \mathrm{C}-1,200^{\circ} \mathrm{C}$ for the experimental protocol because this temperature range was similar to that of the actual fire cases. From the knowledge about the properties of burnt bone already discussed in this review, the bones they burnt are thought to have been severally shrunk and colored white. Follow-on studies conducted more detailed experiments on burning temperature and time, as well as assessing amplification product size. ${ }^{28,36,45}$ These studies experimentally burnt bovine compact bones at up to a maximum of $250^{\circ} \mathrm{C}$ using a variety of increments ranging from $10^{\circ} \mathrm{C}$ to $50^{\circ} \mathrm{C}$ in each study. The DNA was then extracted and subsequent polymerase chain reaction (PCR) processes targeted nuclear DNA and mitochondrial DNA, both with varied target lengths. Their results indicated that the DNA consistently failed to be amplified, even at only $210^{\circ} \mathrm{C}$ for 2 hours ${ }^{36,45}$ and at $200^{\circ} \mathrm{C}$ for 45 minutes. ${ }^{28}$ The correlation between target length and PCR success has also been shown through these three studies. The shorter PCR target region tended to be more resistant to the high temperatures from burning. Tsuchimochi et al have performed a similar experiment using teeth. ${ }^{77}$ They attempted to amplify Y-chromosomal DNA extracted from dental pulps of heated teeth and failed to amplify this even in the teeth heated at $400^{\circ} \mathrm{C}$ for 2 minutes. In this study, the threshold temperature for amplification success was higher than those shown in the three previously mentioned studies. However, considering that the dental pulp is somewhat protected from heat by the surrounding enamel and dentine, this severe DNA degradation after such a short period of heating also suggests the poor heat resistance of DNA.

In contrast to these studies, Schwark et al achieved better results from DNA amplifications of burnt bones obtained from actual cases. ${ }^{33}$ They classified the degree of burning according to bone color and successfully achieved amplification from the specimens at the highest degree of burning, colored "blue-gray-white". This coloration would suggest that the burning temperatures reached over $500^{\circ} \mathrm{C}$ so the amplification success seems to contradict the results obtained from other studies. However, there is a plausible explanation for this contradiction. Schwark et al used a self-made multiplex PCR system optimized for amplifying highly degraded DNA by shortening the target length for PCRs and also used a commercially available nuclear DNA typing kit with a higher number of PCR cycles to increase sensitivity. ${ }^{33,78}$ It is possible that their highly sensitive typing system might 
work well on severely degraded DNA, but the unevenness of burning in casework, even within a single bone, cannot be ignored. The portion chosen for DNA extraction might have been exposed to a lesser degree than the dominant area used for classification of burn coloration. Further experimental study of burning bone under strict temperature control would be required to clarify this matter.

\section{Advanced technology for observing burnt bones}

As already explained in this review, burnt bones present many problems for forensic identification. These extend into both anthropological and DNA analysis and we should not expect to consistently obtain sufficient DNA profiles from severely burnt bones. In such situations, anthropological results become more important as the means for forensic identification. We therefore need to obtain as much morphological information as possible from fragmented and fragile burnt bones.

The micro-CT imaging technique is one of the most advanced technologies available for observing the detailed morphology of small materials. ${ }^{79-85}$ It enables us to obtain not only surface layer three-dimensional (3D) shapes of fragmented bone but also its corresponding sliced histological image without any destructive preparation of fragile, severely burnt bone. The micro-CT scanning system employs two main units: a micro-focal X-ray source and a high-resolution X-ray detector. There are two designs of geometry for these two units to collect $360^{\circ}$ projections

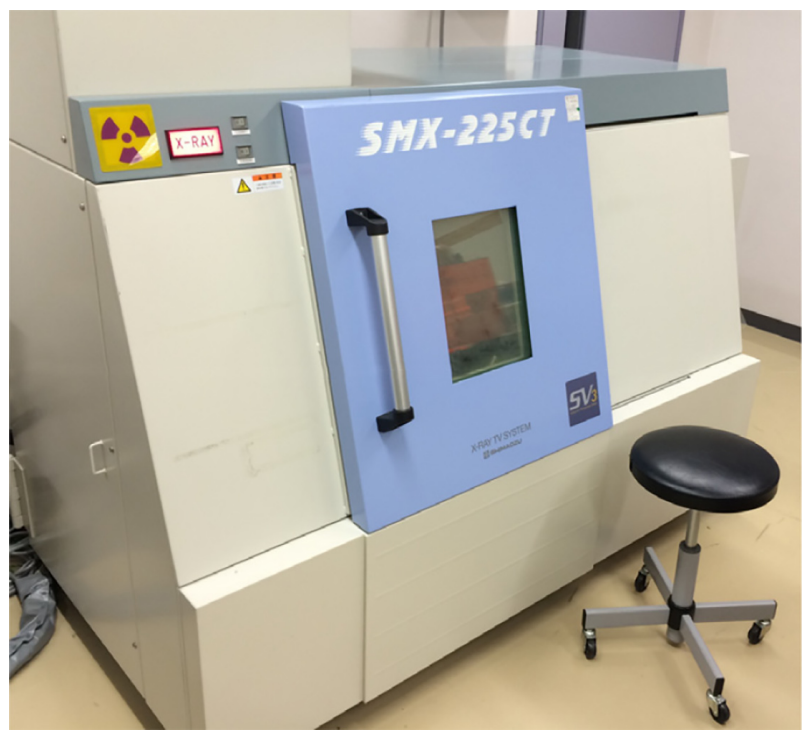

Figure I A micro-CT system, exterior appearance. Abbreviation: micro-CT, micro-computed tomography.

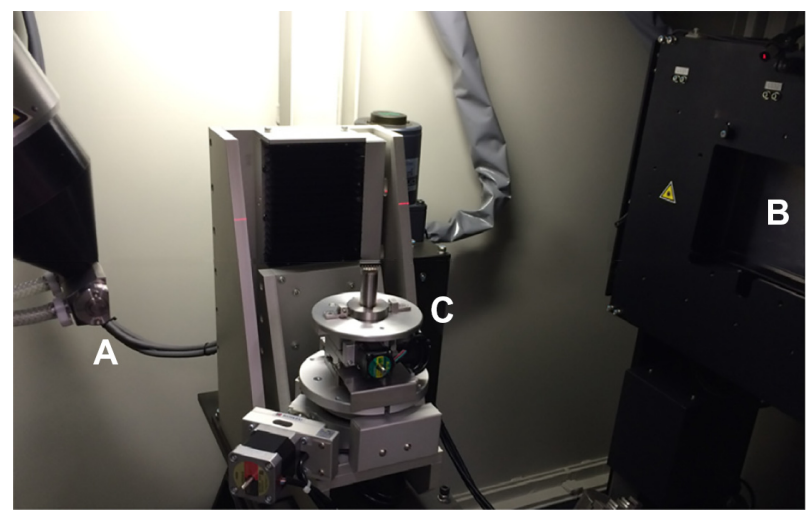

Figure 2 Interior view of the micro-CT system: (A) a micro-focal X-ray source, (B) a high-resolution $\mathrm{X}$-ray detector, and $(\mathbf{C})$ a precise manipulator. Abbreviation: micro-CT, micro-computed tomography.

from an object: ${ }^{79} 1$ ) rotating the gantry consists of diagonally positioned X-ray tube and detector, ie, it is scaled-down conventional medical CT scanner and 2) rotating the object placed on a precise manipulator. ${ }^{80}$ An example of the latter type of the micro-CT system is shown in Figures 1 and 2. The micro-focal X-ray spread from the source projects enlarged image of the object onto the detector, and the manipulator precisely rotates the object during a scanning (Figure 2). The object size available for scanning varies by the type of the scanner. Our system shown in Figure 1 scans objects sized between approximately 2 and $150 \mathrm{~mm}$ in diameter. Many applications of the micro-CT system to research uses have been reported in a wide range of areas not only in bone
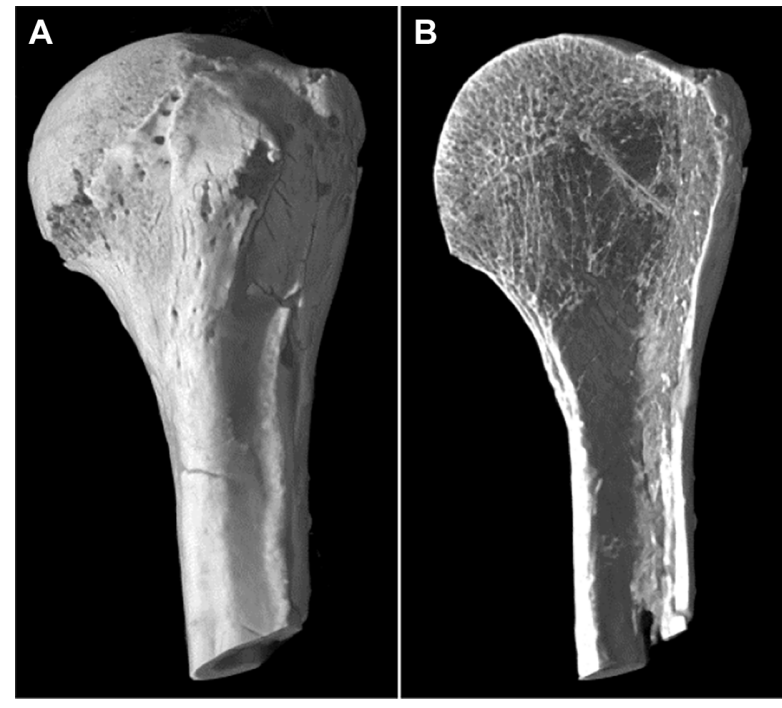

Figure 3 Three-dimensional (3D) images of cremated proximal end of humerus, obtained by micro-CT imaging.

Notes: Detailed structure of sponge bone can be observed by virtually slicing the 3D image. (A) 3D image before virtual slicing and (B) interior view of the humerus after virtual slicing.

Abbreviation: micro-CT, micro-computed tomography. 


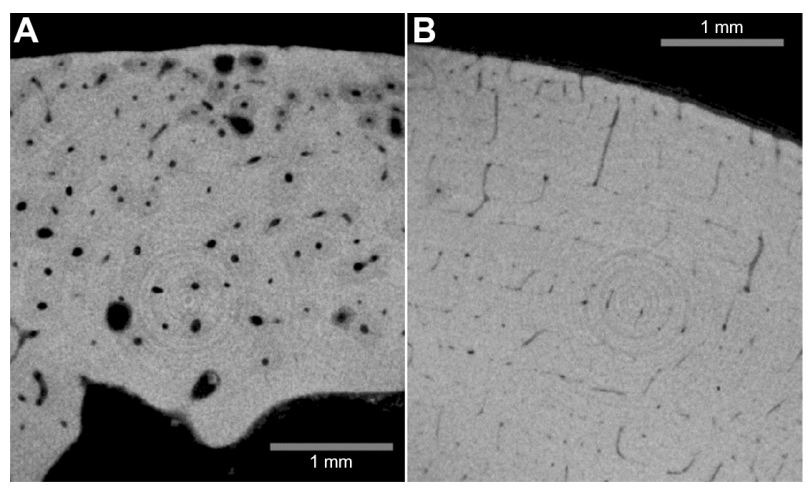

Figure 4 Enlarged images of the compact bones obtained by intensely focused CT slicing.

Notes: Histological structures can be seen clearly and the lamellar pattern is found in bovine specimen. (A) Human tibia and (B) bovine metacarpal bone. Abbreviation: CT, computed tomography.

and dental anatomy ${ }^{81-83}$ but also in archaeology to observe bodies of arthropods in fossil remains, ${ }^{80}$ in neuroanatomy to observe nervous system of arthropods, ${ }^{84}$ in cardiology to obtain cardiovascular images of mice, ${ }^{79,85}$ and so on. Highly advanced technology, synchrotron radiation micro-CT has also been applied to observing detailed histological structures of the compact bone. ${ }^{86}$

Two examples where the micro-CT imaging has been applied to bones are shown in Figures 3 and 4. Figure 3 shows the reconstructed $3 \mathrm{D}$ image of the proximal end of a humerus that had been completely cremated. The 3D shape was virtually cut longitudinally, and the detailed structure of spongy bone was revealed. The age estimation can be done from this image based on the metamorphosis of cancellous and trabecular structures of the spongy bone, comparing the changes in overall morphology through various stages of life. ${ }^{87,88}$ The burnt bone is too fragile to be cut mechanically, so this CT imaging is essential to be able to observe the inner structure of the bone. Figure 4 shows enlarged images of the human and bovine compact bones obtained using intensely focused CT slicing. Histological structures such as osteons and Haversian canals can be clearly seen and the lamellar pattern is clear in the bovine specimen. Though these images are of nonburnt specimens, it is thought that an equivalent histological observation would be possible with burnt specimens. As this has shown, micro-CT imaging has huge potential for forensic burnt bone identification because of its high resolution both in reconstructed 3D shapes and in single CT slices.

\section{Conclusion}

A number of investigative studies on burnt bone identification were discussed in this review. This research issue has been studied over a long period of time from a wide range of perspectives in various areas of expertise. Although important findings continue to accumulate, identification methods for burnt bone are still at an early stage of development. Although burnt bone poses many difficulties for forensic identification, current advancements in chemical and physical analyses, X-ray imaging, and DNA analysis have the potential to provide higher scientific certainty for the results of identification attempts. Continued application of more advanced technology is expected to provide more opportunities to increase our knowledge in this field.

\section{Acknowledgment}

The author wishes to thank the anonymous reviewers for their helpful comments.

\section{Disclosure}

The author reports no conflicts of interest in this work.

\section{References}

1. Holck P. Cremated Bones. A medical-anthropological study of an archaeological material on cremation burials. 2nd ed. Anthropologiske skrifter nr. 1b. Oslo: Anatomical Institute, University of Oslo; 1996.

2. Devlin JB, Herrmann NP. Bone color as an interpretive tool of the depositional history of archaeological cremains. In: Schmidt CW, Symes SA, editors. The Analysis of Burned Human Remains. London: Academic Press; 2008:109-128.

3. Walker PL, Miller KWP, Richman R. Time temperature, and oxygen availability: an experimental study of the effects of environmental conditions on the color and organic content of cremated bone. In: Schmidt CW, Symes SA, editors. The Analysis of Burned Human Remains. London: Academic Press; 2008:129-135.

4. Dehaan JD. Fire and bodies. In: Schmidt CW, Symes SA, editors. The Analysis of Burned Human Remains. London: Academic Press; 2008:1-13.

5. Fairgrieve SI. The cremation process. In: Fairgrieve SI, ed. Forensic Cremation - Recovery and Analysis. Boca Raton: CRC Press; 2008:37-60.

6. Fairgrieve SI. Heat-induced alterations of bone microstructure. In: Fairgrieve SI, ed. Forensic Cremation - Recovery and Analysis. Boca Raton: CRC Press; 2008:131-140.

7. Byers SN. Postmortem changes to bone. In: Byers SN, ed. Introduction to Forensic Anthropology. 2nd ed. Boston: Pearson; 2004: 383-405.

8. Thompson T. Burned human remains. In: Blau S, Ubelaker DH, editors. Handbook of Forensic Anthropology and Archaeology. Walnut Creek (CA): Left Coast Press; 2009:295-303.

9. Mayne Correia PM. Fire modification of bone: a review of the literature. In: Hagland WD, Sorg MH, editors. Forensic Taphonomy - The Postmortem Fate of Human Remains. Boca Raton: CRC Press; 1997:275-293.

10. Ellingham STD, Thompson RJU, Islam M, Taylor G. Estimating temperature exposure of burnt bone - a methodological review. Sci Justice. 2015;55:181-188.

11. Ubelaker DH. The forensic evaluation of burned skeletal remains: a synthesis. Forensic Sci Int. 2009;183:1-5.

12. Thompson TJU. Recent advances in the study of burned bone and their implications for forensic anthropology. Forensic Sci Int. 2004;146(Suppl):S203-S205.

13. Fairgrieve SI. Scene recovery. In: Fairgrieve SI, editor. Forensic Cremation - Recovery and Analysis. Boca Raton (FL): CRC Press; 2008:61-90. 
14. MundorffAZ. Anthropologist-directed triage: three distinct mass fatality events involving fragmentation of human remains. In: Adams BJ, Byrd JE, editors. Recovery, Analysis, and Identification of Commingled Human Remains. Totowa (NJ): Humana Press; 2008:123-144.

15. Mayne Correia PM, Beattie O. A critical look at methods for recovering, evaluating, and interpreting cremated human remains. In: Hagland WD, Sorg MH, editors. Advances in Forensic Taphonomy - Method, Theory, and Archaeological Perspectives. Boca Raton: CRC Press; 2002:435-450.

16. Dirkmaat DC. Recovery and interpretation of the fatal fire victim: the role of forensic anthropology. In: Hagland WD, Sorg MH, editors. Advances in Forensic Taphonomy - Method, Theory, and Archaeological Perspectives. Boca Raton: CRC Press; 2002:451-472.

17. Warren M. Detection of commingling in cremated human remains In: Adams BJ, Byrd JE, editors. Recovery, Analysis, and Identification of Commingled Human Remains. Totowa (NJ): Humana Press; 2008:185-197.

18. Schultz JJ, Warren MW, Krigbaum JS. Analysis of human cremains: gross and chemical methods. In: Schmidt CW, Symes SA, editors The Analysis of Burned Human Remains. London: Academic Press; 2008:75-94.

19. Bennett JL, Benedix DC. Positive identification of cremains recovered from an automobile based on presence of an internal fixation device. J Forensic Sci. 1999;44(6):1296-1298.

20. Eckert WG, James S, Katchis S. Investigation of cremation and severely burned bodies. Am J Forensic Med Pathol. 1998;9(3):188-200.

21. Murray KA, Rose JC. The analysis of cremains: a case study involving the inappropriate disposal of mortuary remains. J Forensic Sci. 1993;38(1):98-103.

22. Fanton L, Jdeed K, Tilhet-Coartet S, Malicier D. Criminal burning Forensic Sci Int. 2006;158:87-93.

23. Porta D, Poppa P, Regazzola V, et al. The importance of an anthropological scene of crime investigation in the case of burnt remains in vehicles 3 case studies. Am J Forensic Med Pathol. 2013;34(3):195-200.

24. Bontrager AB, Nawrocki SP. A taphonomic analysis of human cremains from the Fox Hollow Farm serial homicide site. In: Schmidt CW, Symes SA, editors. The Analysis of Burned Human Remains. London: Academic Press; 2008:211-226.

25. Fairgrieve SI. Positive identification of cremains. In: Fairgrieve SI, ed. Forensic Cremation - Recovery and Analysis. Boca Raton: CRC Press; 2008:161-182.

26. Owsley DW. Identification of the fragmentary, burned remains of two US journalists seven years after their disappearance in Guatemala J Forensic Sci. 1993;38(6):1372-1382.

27. Thompson TJU. Heat-induced dimensional changes in bone and their consequences for forensic anthropology. J Forensic Sci. 2005;50(5):1008-1015.

28. Imaizumi K, Taniguchi K, Ogawa Y. DNA survival and physical and histological properties of heat-induced alterations in burnt bones. Int J Legal Med. 2014;128:439-446.

29. Quatrehomme G, Bolla M, Muller M, et al. Experimental single controlled study of burned bones: contribution of scanning electron microscopy. J Forensic Sci. 1998;43(2):417-422.

30. Holden JL, Phakey PP, Clement JG. Scanning electron microscope observations of heat-treated human bone. Forensic Sci Int. 1995;74: 29-45.

31. Stiner MC, Kuhn SL. Differential burning, recrystallization, and fragmentation of archaeological bone. J Archaeol Sci. 1995;22:223-237.

32. Strydonck MV, Boudin M, De Mulder G. The carbon origin of structural carbonate in bone apatite of cremated bones. Radiocarbon. 2010;52: 578-586

33. Schwark T, Heinrich A, Preuße-Prange A, Wurmb-Schwark NV. Reliable genetic identification of burnt human remains. Forensic $\mathrm{Sci}$ Int Genet. 2011;5:393-399.

34. Holden JL, Phakey PP, Clement JG. Scanning electron microscope observations of incinerated human femoral bone: a case study. Forensic Sci Int. 1995;74:17-28.
35. Glassman DM, Crow RM. Standardization model for describing the extent of burn injury to human remains. J Forensic Sci. 1996; 41(1):152-154.

36. Fredericks JD, Ringrose TJ, Dicken A, Williams A, Bennett P. A potential new diagnostic tool to aid DNA analysis from heat compromised bone using colorimetry: a preliminary study. Sci Justice. 2015;55: 124-130.

37. Munsell Color [homepage on the Internet]. Grand Rapids (MI): Munsell Color. Available from: http://munsell.com/. Accessed August 25, 2015.

38. Kalsbeek N, Richter J. Preservation of burned bones: an investigation of the effects of temperature and $\mathrm{pH}$ on hardness. Stud Conserv. 2005;51:123-138.

39. Warren MW, Maples WR. The anthropometry of contemporary commercial cremation. J Forensic Sci. 1997;42(3):417-423.

40. Bass WM, Jantz RL. Cremation weights in east Tennessee. J Forensic Sci. 2004;49(5):901-904.

41. Trotter M, Peterson BR. Ash weight of human skeletons in per cent of their dry, fat-free weight. Anat Rec. 1995;123(3):341-358.

42. Grupe G, Hummel S. Trace element studies on experimentally cremated bone. I. Alteration of the chemical composition at high temperatures. J Archaeol Sci. 1991;18:177-186.

43. Hiller JC, Thompson TJU, Evison MP, Chamberlain AT, Wess TJ. Bone mineral change during experimental heating: an X-ray scattering investigation. Biomaterials. 2003;24:5091-5097.

44. Ortner DJ, Turner-Walker G. The biology of skeletal tissues. In: Ortner DJ, ed. Identification of Pathological Conditions in Human Skeletal Remains. 2nd ed. London: Academic Press; 2003:11-35.

45. Fredericks JD, Bennett P, Williams A, Rogers KD. FTIR spectroscopy: a new diagnostic tool to aid DNA analysis from heated bone. Forensic Sci Int Genet. 2012;6:375-380.

46. Harvig L, Lynnerup N. On the volume of cremated remains - a comparative study of archaeologically recovered cremated bone volume as measured manually and assessed by computed tomography and by stereology. J Archaeol Sci. 2013;40:2713-2722.

47. Gonçalves D. The reliability of osteometric techniques for the sex determination of burned human skeletal remains. Homo. 2011;62: 351-358.

48. Grévin G, Bailet P, Quatrehomme G, Ollier A. Anatomical reconstruction of fragments of burned human bones: a necessary means for forensic identification. Forensic Sci Int. 1998;96:129-134.

49. Delattre VF. Burned beyond recognition: systematic approach to the dental identification of charred human remains. J Forensic Sci. 2000;45(3):589-596.

50. Bradtmiller B, Buikstra JE. Effects of burning on human bone microstructure: a preliminary study. J Forensic Sci. 1984;29(2):535-540.

51. Nelson R. A microscopic comparison of fresh and burned bone. J Forensic Sci. 1992;37(4):1055-1060.

52. Cattaneo C, DiMartino S, Scali S, Craig OE, Grandi M, Sokol RJ. Determining the human origin of fragments of burnt bone: a comparative study of histological, immunological and DNA techniques. Forensic Sci Int. 1999;102:181-191.

53. Kerley ER. The microscopic determination of age in human bone. Am J Phys Anthropol. 1965;23(2):149-163.

54. Ahlquist J, Damsten O. A modification of Kerley's method for microscopic determination of age in human bone. J Forensic Sci. 1969; 14(2):204-221.

55. Kerley ER. Age determination of bone fragments. J Forensic Sci. 1969; 14(1):59-67.

56. Singh IJ, Gunberg DL. Estimation if age at death in human males from quantitative histology of bone fragments. Am J Phys Anthropol. 1970;33(3):373-382.

57. Kerley ER, Uberaker DH. Revisions in the microscopic method of estimating age at death in human cortical bone. Am J Phys Anthropol. 1978;49:545-546.

58. Thompson DD. The core technique in the determination of age at death in skeletons. J Forensic Sci. 1979;24(4):902-915. 
59. Yoshino M, Imaizumi K, Miyasaka S, Seta S. Histological estimation of age at death using microradiographs of humeral compact bone. Forensic Sci Int. 1994;64:191-198.

60. Hillier ML, Bell LS. Differentiating human bone from animal bone: a review of histological methods. J Forensic Sci. 2007;52(2): 249-263.

61. Martiniaková M, Grosskopf B, Omelka R, Vondráková M, Bauerová M. Differences among species in compact bone tissue microstructure of mammalian skeleton: use of a discriminant function analysis for species identification. J Forensic Sci. 2006;51(6):1235-1239.

62. Inoi $\mathrm{T}$, Yoshino M, Seta S. Histological investigation of human and animal bone fragments by microradiography and its application to a forensic case (in Japanese). Report of the National Research Institute of Police Science. 1994;47(3):28-37.

63. Sawada J, Nara T, Nakajima T, Saito Y, Dodo Y, Hirata K. Histomorphological discrimination between human and nonhuman bones of fragmentary osteal remains: analyses of burnt bones from the ancient Heian site in the northern Tohoku district, Japan (in Japanese). Anthropol Sci. 2010;118(1):23-36.

64. Mori R, Kodaka T, Soeta S, et al. Preliminary study of histological comparison on the growth patterns of long-bone cortex in young calf, pig, and sheep. J Vet Med Sci. 2005;67(12):1223-1229.

65. Mulhern DM. Differentiating human from nonhuman skeletal remains. In: Blau S, Ubelaker DH, editors. Handbook of Forensic Anthropology and Archaeology. Walnut Creek (CA): Left Coast Press; 2009:153-163.

66. Weiner S, Bayosef O. States of preservation of bones from prehistoric sites in the near-east - a survey. J Arch Sci. 1990;17:187-196.

67. Castillo RF, Ubelaker DH, Acosta JAL, de la Rosa RJE, Garcia IG. Effect of temperature on bone tissue: histological changes. J Forensic Sci. 2013;58(3):578-582.

68. Waterhouse K. Post-burning fragmentation of calcined bone: implications for remains recovery from fetal fire scenes. J Forensic Leg Med. 2013;20:1112-1117.

69. Waterhouse K. The effect of weather conditions on burnt bone fragmentation. J Forensic Leg Med. 2013;20:489-495.

70. Pope EJ, Smith OC. Identification of traumatic injury in burned cranial bone: an experimental approach. J Forensic Sci. 2004;49(3): 431-440.

71. Poppa P, Porta D, Gibelli D, et al. Detection of blunt, sharp force and gunshot lesions on burnt remains - a cautionary note. Am J Forensic Med Pathol. 2011;32(3):275-279.

72. Robbins SC, Fairgrieve SI, Oost TS. Interpreting the effects of burning on pre-incineration saw marks in bone. J Forensic Sci. 2015;60(Suppl 1): S182-S187.

73. Amadasi A, Merli D, Brandone A, Cattaneo C. Chromatic variation of soot soiling: a possible marker for gunshot wounds in burnt bone. J Forensic Sci. 2014;59(1):195-198.
74. Hochmeister MN, Budowle B, Borer UV, Eggmann U. Comey CT, Drinhofer R. Typing of deoxyribonucleic acid (DNA) extracted from compact bone from human remains. J Forensic Sci. 1991;36:1649-1661.

75. Imaizumi K, Noguchi K, Shiraishi T, et al. DNA typing of bone specimens - the potential use of the profiler test as a tool for bone identification. Legal Med. 2005;7:31-41.

76. Imaizumi K, Saitoh K, Sekiguchi K, Yoshino M. Identification of fragmented bones based on anthropological and DNA analysis: case report. Legal Med. 2002;4:251-256.

77. Tsuchimochi T, Iwasa M, Maeno Y, et al. Chelating resin-based extraction of DNA from dental pulp and sex determination from incinerated teeth with Y-chromosomal alphoid repeat and short tandem repeats. Am J Forensic Med Pathol. 2002;23(3):268-271.

78. von Wurmb-Schwark N, Preusse-Prange A, Heinrich A, Simeoni E, Bosch T, Schwark T. A new multiplex-PCR comprising autosomal and y-specific STRs and mitochondrial DNA to analyze highly degraded material. Forensic Sci Int Genet. 2009;3:96-103.

79. Badea CT, Drangova M, Holdsworth DW, Johnson GA. In vivo small animal imaging using micro-CT and digital subtraction angiography. Phys Med Biol. 2008;53(19):R319-R350.

80. Liu Y, Scholtz G, Hou X. When a 520 million-year-old Chemgjiang fossil meets a modern micro-CT - a case study. Sci Rep. 2015;5:12802.

81. Dessel JV, Huang Y, Depypere M, Rubira-Bullen I, Maes F, Jacobs R. A comparative evaluation if cone beam CT and micro-CT on trabecular bone structures in the human mandible. Dentmaxillofac Radiol. 2013;42(8):20130145.

82. Hsu J-T, Ho Y-J, Huang H-L, et al. A comparison of micro-CT and dental CT in assessing cortical bone morphology and trabecular bone microarchitecture. PLoS One. 2014;9(9):e107545.

83. Swain MV, Xue J. State of the art of micro-CT applications in dental research. Int J Oral Sci. 2009;1(4):177-188.

84. Sombke A, Lipke E, Michalik P, Uhl G, Harzsch S. Potential and limitation of X-ray micro-computed tomography in arthropod neuroanatomy: a methodological and comparative survey. J Comp Neurol. 2015;523: 1281-1295.

85. Kim AJ, Francis R, Liu X, et al. Micro-computed tomography provides high accuracy congenital heart disease diagnosis in neonatal and fetal mice. Circ Cardiovasc Imaging. 2013;6(4):551-559.

86. Cooper DML, Erickson B, PeeleAG, Hannah K, Thomas CDL, Clement JG. Visualization of $3 \mathrm{D}$ osteon morphology by synchrotron radiation micro-CT. J Anat. 2011;219:481-489

87. Walker RA, Lovejoy CO. Radiographic changes in the clavicle and proximal femur and their use in the determination of skeletal age at death. Am J Phys Anthropol. 1985;68:67-78.

88. Krogman WM, Işcan MY. Chapter 5 Skeletal age: postcranium - 8 . Radiographic method. In: Krogman WM, Işcan MY, editors. The Human Skeleton in Forensic Medicine. 2nd ed. Springfield (IL): Charles C Thomas Publisher; 1986:169-188.
Research and Reports in Forensic Medical Science

\section{Publish your work in this journal}

Research and Reports in Forensic Medical Science is an international, peer-reviewed, open access journal publishing original research, reports, reviews and commentaries on all areas of forensic medical science. The manuscript management system is completely online and includes a

\section{Dovepress}

very quick and fair peer-review system. Visit http://www.dovepress.com/ testimonials.php to read real quotes from published authors. 